\title{
Description of Sybota compagnuccii, a new spider species from Patagonia, Argentina (Araneae, Uloboridae)
}

\author{
Cristian J. GRISMADO \\ División Aracnología, Museo Argentino de Ciencias Naturales «Bernardino Rivadavia», Av. Angel \\ Gallardo 470, C1405DJR Buenos Aires, Argentina, e-mail: grismado@macn.gov.ar.
}

\begin{abstract}
Description of Sybota compagnuccii a new spider species from Patagonia, Argentina (Araneae, Uloboridae). Sybota compagnuccii new species is described for the Argentinian Patagonia (Neuquén, Río Negro and Chubut Provinces). Relationships with the previously described Sybota species are discussed.
\end{abstract}

Key words: Araneae, Uloboridae, Sybota, Taxonomy, Patagonia, Argentina.

The uloborid spider genus Sybota Simon 1892, comprises five species: two from Central and Southern Chile, S. abdominalis (Nicolet) and S. osornis Opell and three from Argentina, S. rana (Mello-Leitão), S. mendozae Opell and S. atlantica Grismado (Platnick, 2007). One of the most remarkable features of the genus Sybota (convergent with the genus Polenecia Lehtinen) is the abdominal caudal projection that extends beyond the spinnerets (Fig. 4; Opell 1979, figs. 51, 102, 110, 116; Grismado 2001, figs. 1, 3). The female genitalia of Sybota species have a partially entelegyne condition (Fig. 13, Grismado 2001, fig. 10); and the males have a well developed con-ductor and a median apophysis with two or three projections (Figs. 5- 10; Opell 1979, figs. 6A- B; Grismado 2001, figs. 5-7). Coddington (1990), in the last published cladistic analysis of the fam-ily, suggested that Sybota is the sister group of the clade Orinomana Strand + (Hyptiotes Wal-ckenaer + Miagrammopes O. P.Cambridge), all of them united by having the posterior lateral eyes on conspicuous tubercles of carapace.

In a previous paper (Grismado, 2001), I pro-posed a monophyletic group within the genus Sybota that comprises the Argentine species, all of them share the following putative synapo-morphies: long cephalotorax, anterior median eyes on a prominent tubercle, females with long sperm ducts and males (at least in $S$. atlantica) with the embolus longer than those of the Chilean species.

In this contribution I describe a new species, $S$. compagnuccii, from the Andean forests of Neuquén, Río Negro and Chubut provinces, in the Argentinian Patagonia, that lacks the synapomorphies above mentioned, resembling more to the chilean than to the argentinian mem-bers of the genus.

\section{MATERIALS AND METHODS.}

The specimens here studied are deposited in the National Collection of Arachnology of the Museo Argentino de Ciencias Naturales «Bernardino Rivadavia», Buenos Aires (MACN-Ar, Cristina L. Scioscia). The format of descrip-tions and terminology of genital structures fol-lows mostly Opell (1979). As in a previous paper (Grismado, 2001) I follow this nomenclature in the male palpal sclerites only for ease compari-son with previously described species. I also dis-criminated in this paper the three projections of the median apophysis for descriptive purposes (dorsal, median and ventral; Fig. 7). Coddington (1990) suggested that the terms median apophy-sis and conductor must be switched, although he recognized that the homology of this sclerites in uloborids is still unsolved. The abbreviations used in the text are as follows: $\mathrm{BH}=$ basal haematodocha; $\mathrm{C}=$ conductor; $\mathrm{CD}=$ copulatory duct; $\mathrm{CO}=$ copulatory opening; $\mathrm{Cy}=$ cymbium; $\mathrm{E}=$ embolus; $\mathrm{F}=$ fundus; $\mathrm{FD}=$ fertilization duct; $\mathrm{MA}=$ median apophysis; $\mathrm{MH}=$ median haematodocha; $\mathrm{PP}=$ posterior plate; $\mathrm{S}=$ spermatheca; $\mathrm{ST}=$ subtegulum; $\mathrm{T}=$ tegulum. Abbreviations for eyes are the standard for Araneae. The drawings were made with cam-era lucida mounted on a stereoscopic compound microscope Leitz Wetzlar; the photographs of preserved specimens were taken with a digital camera Nikon DXM 1200 mounted on a stere-oscopic compound microscope Nikon SMZ 1500; male palp was expanded in $\mathrm{KOH}$ solu-tion and transferred to distilled water. The epigynum was cleared in clove oil for observa-tion. All measurements are expressed in milli-meters. 


\section{SYSTEMATIC DESCRIPTION}

\section{Sybota compagnuccii n. sp.}

(Figs. 1-14)

Types. Male holotype and two females para-types from Argentina, Neuquén Province, Parque Nacional Lanín: Departamento Huiliches: Lago Paimún, 1517.I.1999, Luis A. Compagnucci col. (MACN-Ar 10524, 12347 and 12348 respectively).

Etymology. The species epithet is a patro-nymic in honor to Luis A. Compagnucci, ento-mologist of the MACN, collector of the type se-ries, companion of several field trips and good friend.

Diagnosis. Both sexes differ from the remain-ing species of the genus by having the relatively shorter caudal projection of abdomen (Figs. 1-4). Females resemble those of $S$. abdominalis and $S$. osornis by having a short prosoma and by lack-ing the anterior tubercle for the AME (Fig. 3; Opell 1979, figs. 98, 100-101), but differ by their broader median field of the epigynum (Fig. 11) and a broadened posterior plate (Fig. 12). The male palp is, nevertheless, more similar to that of $S$. atlantica by having the embolus and the conductor longer than the Chilean species and by the shape of the median apophysis: S. abdominalis and $S$. osornis have a rounded ven-tral projection, and the dorsal one is thinner and well separated from the other two prongs by a large concavity (Opell 1979, figs. 6A-B). The me-dian apophysis of S. atlantica and $S$. com-pagnuccii share the more or less equidistant pro-jections (in retrolateral view), with the ventral one shortened, not rounded; moreover, the dor-sal projection is broadened and flattened. The new species here described differs clearly from $S$. atlantica by having a shorter embolus and con-ductor, a longer digitiform prolateral projection of the conductor, a much larger conical projec-tion of the palpal tibia, and by lacking a basal cymbial tubercle (Figs. 5-10, Grismado 2001, figs. 5-7).

Description. Male (holotype): Total length: 3.56, cephalotorax length: 1.40, sternum length: 0.94, abdomen length: 2.30; leg I, length of podomeres: femur 2.92, tibia 2.64, metatarsus 2.96, tarsus 0.78 . Color: Cephalotorax brown with fine dark radial lines, with a thin light median band, more contrasting around the fovea, and diffused on the ocular area (Fig. 1); clypeus and carapace margins yellowish; prosoma completely covered by fine light hairs; eyes bordered by dark brown rings. Sternum with a dark brown «V» design with posteriorly directed tip, posterior and lateral to the «V», reddish; anterior to that, light brown; labium yellowish with whitish anterior border, endites yellowish, lighter at margins. Legs yellowish with a diffuse grey pigment on prolateral sides of femora and tibiae I-II and retrolateral faces of femora, tibiae, and metatarsi III -IV. Abdomen with a less pronounced caudal projection than in other known species, more or less truncated; there is a wide dark dorsal band, almost black in front, light gray in central and posterior parts; conspicuous white guanine deposits at the sides, and four pairs of black spots (Fig. 1); from the anterior part of abdomen two laterally directed dark bands that continue along both sides, becoming more wide and diffuse un-til joining with the dorsal pattern in the caudal projection. Ventrally there is a dark brown pre-epigastric area that continues as a wide dark ven-tral band; sides with white guanine deposits; spinnerets yellowish brown except the posterior face of PMS, dark grey.

Palp: Tibia with a large conical projection; plateshaped subtegulum visible in the resting palp (prolateral view); basal and median hae-matodochae present (Figs. 8-9, visible with ex-pansion); ejaculatory duct sinuous, also visible through the tegulum; embolus encircling poste-roventrally the median apophysis; conductor with a large digitiform projection in the prolateral side (Figs. 5-6, 9-10); median apophysis with three equidistant projections, the dorsal one flat-tened and pointing upwards (in retrolateral view), the median projection is the largest, and the ventral projection is short and with irregu-lar outline (Figs. 6, 7-10).

Female (paratype MACN-Ar 12347): Total length: 5.25, cephalotorax length: 1.60 , sternum length: 1.12 , abdomen length: 3.64; leg I, length of podomeres: femur 2.48, tibia 2.00, metatarsus 2.08, tarsus 0.68. Color: Carapace as in the male but slightly lighter and without the dorsal stripe (Fig. 3); eyes and legs as in the male, except the darkened distal part of tibiae I-II (Fig. 4). Ster-num as in the male, endites and labium uniformly yellowish. Abdomen (Figs. 3, 4) with relatively short and rounded caudal projection, color simi-lar as the male except by the shorter dorsal band (reaching until the first pair of black spots) and by the lateral dark areas, that are replaced by four diffuse gray bands, each corresponding to the dorsal dark spots; in the venter, the median band is thinner, slightly widened at the cribellum.

Epigynum: Paired atria slightly smaller than those of $S$. osornis and S. abdominalis, with the median field wider (Fig. 11). Posterior plate also 

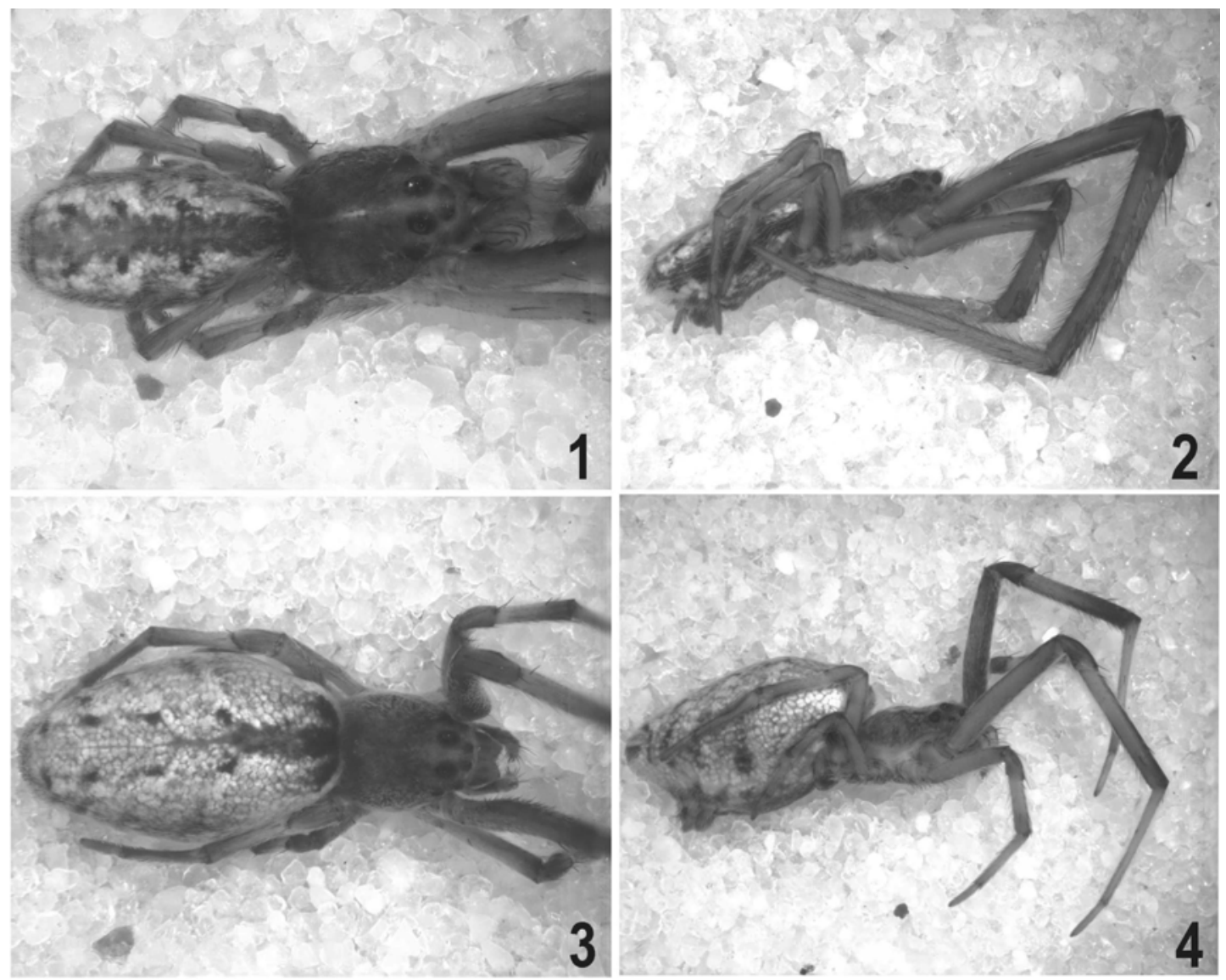

Figs. 1-4: Sybota compagnuccii n. sp., preserved specimens. 1-2, male holotype; 3-4, female paratype. 1, 3, dorsal view; 2, 4, lateral view.

widened, with distinctive sclerotization pointing ventrally (Fig. 12). Large spermathecae, similar to those of the known Chilean species, with copu-latory openings in the margins of the epigynal atria (Fig. 13).

Material examined. ARGENTINA: Neuquén province: Parque Nacional Lanín: Departamento Lácar: Pucará, Lago Lácar, II-1961, dad. M. E. Galiano, 1 m (MACN-AR 5285); VIII-1973, Shacovskoy col., 1 m (MACN-AR 10924); Hua Hum, I-1985, M. J. Ramírez col., 1 f ( MACN-AR 10929); Lago Hermoso; 15 -I-1985, M. J. Ramírez col., 1 f, 1 $m$ (MACN-Ar 10922); Parque Nacional Nahuel Huapi: Departamento Los La-gos: Península Quetrihue, Lag. Patagua y bosque de arrayanes, 23-I1985, M. J. Ramírez col., 1 juv. (MACN-AR 10928); Rio Negro province: Parque Nacional Nahuel Huapi: Departamento Bari-loche: Arroyo Casa de Piedra y Ruta Nac. 240 (1 km from Bariloche), II-1982, M. J. Ramírez col.,
3 f (MACN-AR 10923); Chubut province: Parque Nacional Los Alerces: Departamento Futaleufú: Río Rivadavia, II-1986, M. J. Ramírez col., 1 f (MACNAR 10927); Río Arrayanes, II-1986, M. J. Ramírez col., 1 juv. (MACN-AR 10926); Villa Futalaufquen, II-1986, M. J. Ramírez col., 1 juv. (MACN-AR 10925).

Distribution. Andean forests of Neuquén, Río Negro and Chubut Provinces, Argentina.

\section{DISCUSSION}

Sybota compagnuccii greatly resembles $S$. abdominalis and $S$. osornis in lacking the puta-tive synapomorphies of the other three argentine species, although no quantitative cladistic analy-sis has been carried out for the species in this genus. Nevertheless, I cannot hypothesize syna-pomorphies for these three species; the greatly elongated cone-shaped palpal tibia of these three 


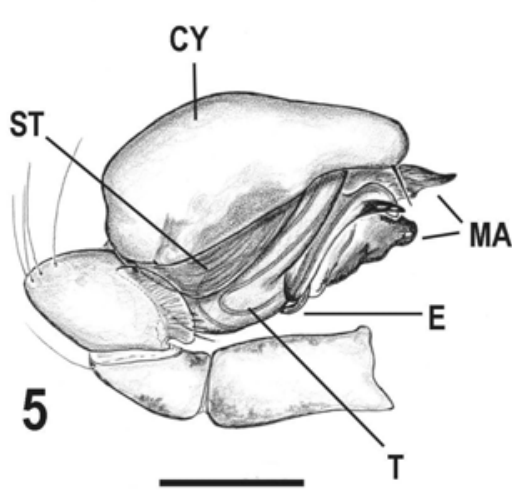

\section{CY}
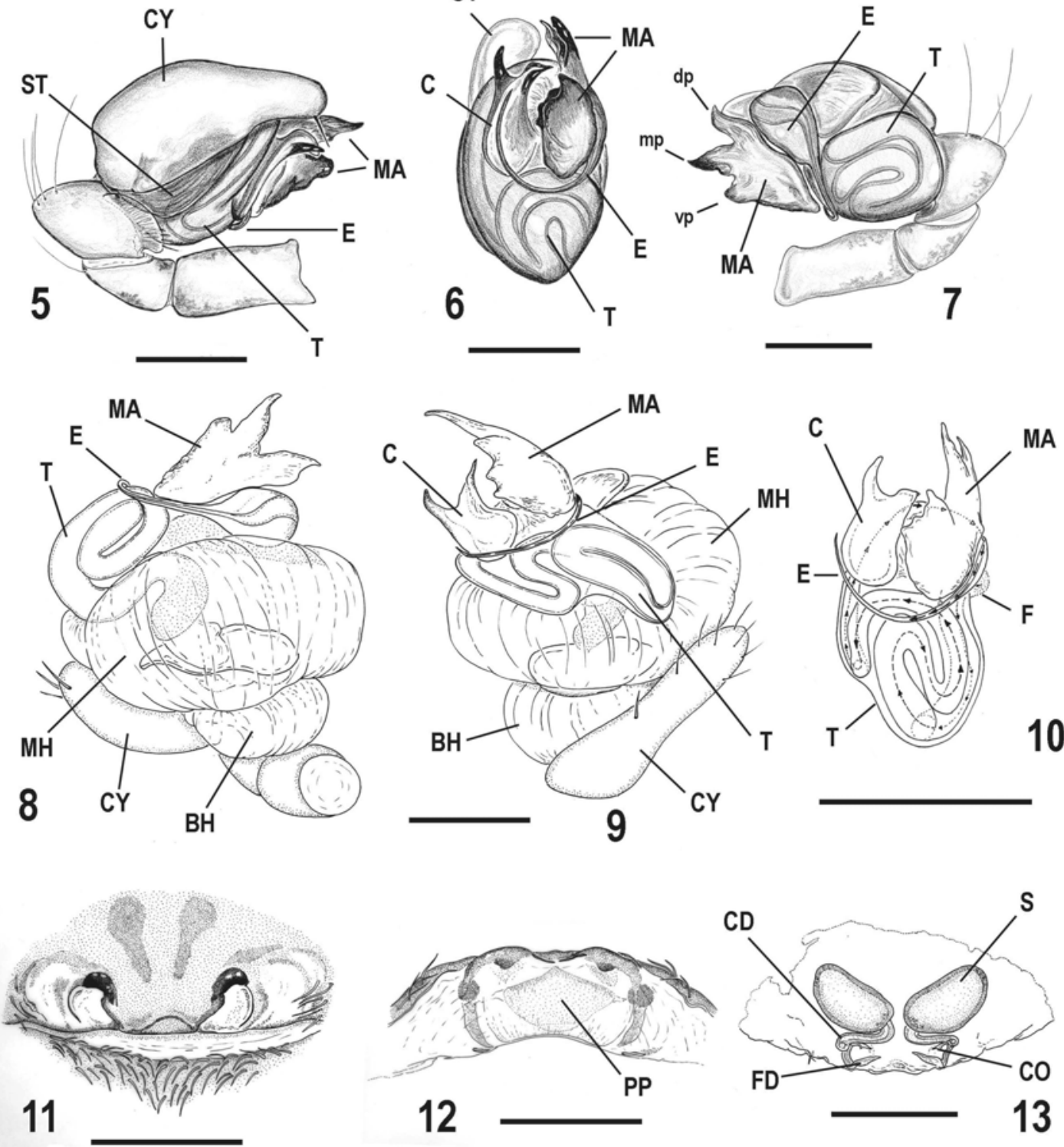

Figs. 5-13: Sybota compagnuccii n. sp. genital morphology. 5-7, male palp (holotype), 5 prolateral, 6 ventral, 7 retrolateral (dp, $\mathrm{mp}$ and $\mathrm{vp}=$ dorsal, median and ventral projections of median apophysis); 8-10, expanded male palp (male from Lago Hermoso), 8 prolateral, 9 retrolateral, 10 apical; 11-13, female genitalia (paratype), 11 epigynum ventral, 12 epigynum posterior, 13 cleared vulva dorsal. Scale bars: $5-12=0.3 \mathrm{~mm} ; 13=0.5 \mathrm{~mm}$. (See other abbreviations in the text).

Austral species is possibly a shared apomorphy (in $S$. atlantica the conical shape is lesser pro-nounced, and the males of $S$. rana and $S$. mendozae remain unknown). However, this char-acter must be taken with some caution, given that most Miagrammopes species have similar fea-tures (Chickering 1968; Opell 1979: fig. 90; Opell 1984: figs. 19-22).
Despite the somatic morphology, the genital bulb of the male looks very similar to that of $S$. atlantica. In contrast, the female genitalic struc-ture more closely resembles those of S. abdo-minalis and S. osornis.

These puzzling combination of morphologi-cal features make the species assemblage more complex than originally suggested by Grismado 


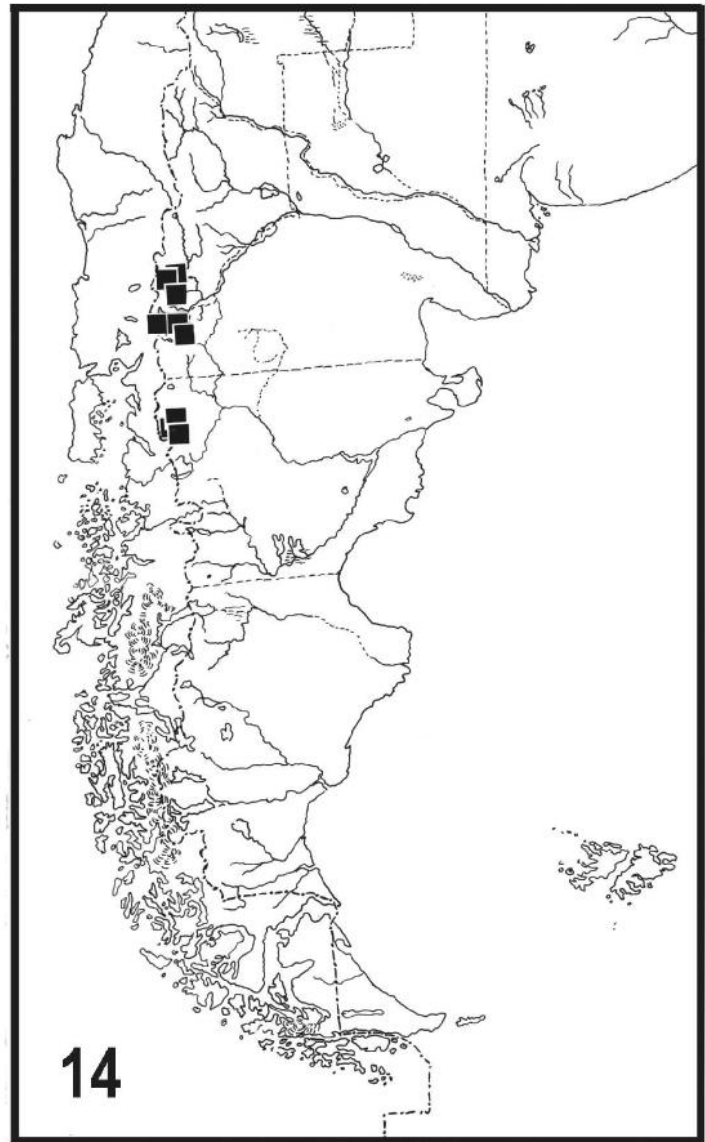

Fig. 14: Geographic distribution of S. compagnuccii, n. sp.

(2001). Consequently, until phylogenetic studies can be conducted, I cannot confidently place $S$. compagnuccii close to any of the known Sybota species.

\section{ACKNOWLEDGEMENTS}

I am very grateful to Martín J. Ramírez, Brent Opell, Cristina L. Scioscia and Gustavo Hormiga for comments and suggestions on the manuscript. I am also indebted to Sergio Archangelsky for editorial comments. This paper is one of a series started during a long convalescence at my home. During this time, Martín J. Ramírez, Cristina Scioscia, Luis Compagnucci, Lara Lopardo and my wife Andrea Raya provided technical assist-ance and moral support. I wish to especially thank them for their invaluable help, encourage-ment and advice during that hard period of my life.

\section{BIBLIOGRAPHY}

Chickering, A. M. 1968. The genus Miagrammopes (Araneae, Uloboridae) in Panama and the West Indies. Breviora 289: 1-28.

Coddington, J. A. 1990. Ontogeny and homology in the male palpus of orb-weaving spiders and their rela-tives, with comments on phylogeny (Araneoclada: Araneoidea: Deinopoidea). Smiths. Contr. Zool. 496: 1-52.

Grismado, C. J. 2001. Notes on the genus Sybota with a description of a new species from Argentina (Araneae, Uloboridae) J. Arachnol. 29: 11-15.

Opell, B. D. 1979. Revision of the genera and tropical American species of the spider family Uloboridae.

Bull. Mus. Comp. Zool. 148: 443-549.

- 1984 . Phylogenetic review of the genus Miagrammopes (sensu lato) (Araneae, Uloboridae). J. Arachnol. 12: 229-240.

Platnick, N. I. 2007. The world spider catalog, version 7.5. American Museum of Natural History, online at http://research.amnh.org/entomology/ spiders/ catalog/index.html 